\title{
MEKANISME KERJA SEL LANGERHANS SEBAGAI SEL PENYAJI ANTIGEN
}

\author{
Octaviana I. S. Rahim \\ Sunny Wangko \\ Sonny J.R. Kalangi
}

\author{
Bagian Anatomi-Histologi Fakultas Kedokteran Universitas Sam Ratulangi Manado \\ Email: indri.rahim@gmail.com
}

\begin{abstract}
Langerhans cells belong to a kind of dendritic cell that functions as an antigen precenting cell. These cells are mostly found in the skin. Some studies suggested that these cells were originated from bone marrow. Langerhans cells can not be identified by using a routine fixation or a usual histological coloration, but by using an electron microscope or a histochemical technique. Birbeck granules are special organelles which exist only in Langerhans cells. Important surface receptors of Langerhans cells are class II MHC, FcER, some integrins, and adhesins. The actions of Langerhans cells are clearly seen in the sensitisation phase of allergic contact dermatitis. In this case, these cells engulf and process antigens of class II MHC, so they can be presented to T cells. Besides processing antigens done by class II MHC, Langerhans cells have CD1 receptors that are not found in other dendritic cells. CD1 molecules present antigens in several forms: lipid, and exogen and endogen glycolipids .
\end{abstract}

Keywords: Langerhans cells, dendritic cells, antigen presenting cells

\begin{abstract}
Abstrak: Sel Langerhans merupakan salah satu jenis sel dendritik yang berfungsi sebagai sel penyaji antigen. Sel ini terbanyak ditemukan di kulit. Beberapa penelitian mengemukakan bahwa sel Langerhans berasal dari sumsum tulang. Sel Langerhans tidak dapat diidentifikasi dengan menggunakan fiksasi rutin atau pewarnaan histologi biasa, tetapi harus dengan mikroskop elektron atau tehnik histokimia. Granula Birbeck ialah organel khas yang hanya terdapat di sel Langerhans. Reseptor permukaan penting yang terdapat pada sel Langerhans yaitu MHC kelas II, FceR dan beberapa integrin serta adhesin. Mekanisme kerja sel Langerhans terlihat jelas pada fase sensitisasi dermatitis kontak alergi yaitu dengan menangkap antigen dan memrosesnya dengan MHC kelas II sehingga dapat disajikan kepada sel T. Selain pemrosesan antigen yang dilakukan oleh MHC kelas II, sel Langerhans memiliki reseptor CD1 yang tidak dimiliki oleh jenis sel dendritik lainnya. Molekul CD1 menyajikan antigen dalam bentuk lipid dan glikolipid baik yang eksogen maupun endogen.
\end{abstract}

Kata kunci: sel Langerhans, sel dendritik, sel penyaji

Tubuh manusia memiliki sistem imun yang berespons terhadap bahan atau partikel asing yang terpapar untuk melindungi tubuh terhadap bahan atau partikel tersebut. Respon imun sangat bergantung pada kemampuan sistem imun untuk mengenali molekul asing (antigen) yang bersifat patogen potensial, dan kemudian mem- bangkitkan reaksi yang tepat untuk menyingkirkan sumber antigen tersebut. ${ }^{1}$ Salah satu jenis respon imun yang mungkin terjadi jika terpapar dengan antigen yaitu respon imun adaptif. Kejadian penting selama terjadinya respon imun adaptif ialah penyajian antigennya. ${ }^{2}$

Pada stadium awal (inisiasi) suatu 
respon imun, sekelompok sel fungsional yang disebut sel penyaji antigen/antigen presenting cell (APC) memfagositosis antigen kemudian menyajikannya kepada limfosit dalam bentuk yang dapat dikenal oleh limfosit. Sel-sel yang dapat bertindak sebagai sel penyaji antigen yaitu sel dendritik, sel Kupffer, sel endotel, fibroblas dan limfosit B.

Seluruh hubungan antara tubuh dan lingkungan luar dibatasi oleh epitel yang berfungsi untuk memberi penghalang fisik terhadap infeksi. Jaringan epitel dan subepitel mengandung sel dendritik epidermal yang disebut sel Langerhans. Sel-sel yang sama ditemukan juga dalam organ-organ limfoid perifer yang kaya akan limfosit $\mathrm{T}$, dan dalam jumlah kecil pada organ lainnya. ${ }^{3}$

\section{SEL PENYAJI ANTIGEN}

Sel penyaji antigen ialah sel yang secara khusus membantu melawan zat asing yang masuk ke dalam tubuh. Sel-sel ini mengirimkan sinyal ke limfosit $\mathrm{T}$ helper/sel Th ketika antigen masuk ke dalam tubuh (Gambar 1). Setiap jenis sel $\mathrm{T}$ khusus dilengkapi untuk menangani jenis patogen berbeda-beda yang dapat berupa bakteri, virus, atau toksin. ${ }^{4}$

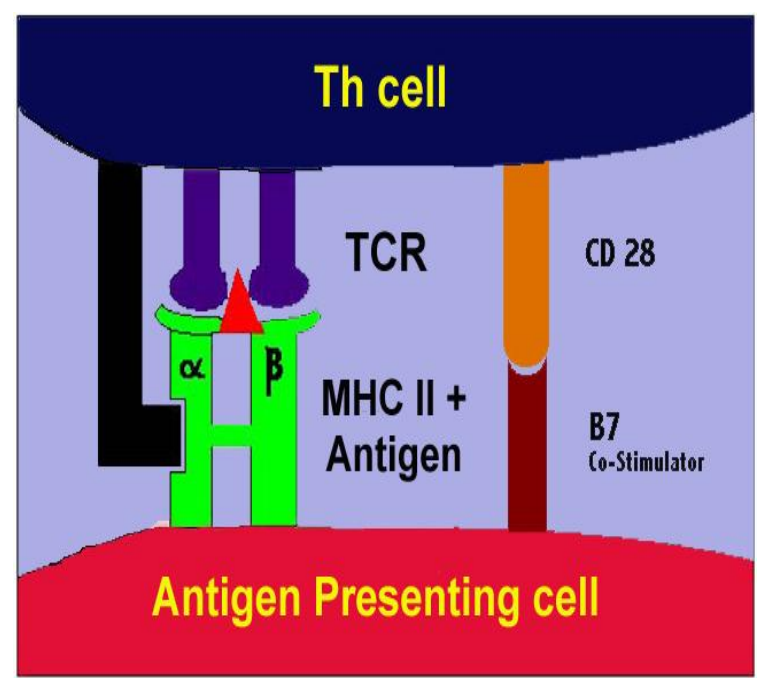

Gambar 1. Interaksi antara sel penyaji antigen dan sel $T$ pembantu (Th cell). Sumber: www.wellness.com/reference/allergies/antigenpresenting-cells. ${ }^{4}$
Sel penyaji antigen dibagi dalam dua kategori yaitu sel penyaji antigen profesional dan non-profesional. Terdapat tiga jenis sel penyaji antigen profesional yang utama yaitu makrofag, sel dendritik dan limfosit B/sel B.

\section{SEL LANGERHANS}

\section{Sejarah}

Berawal pada tahun 1868 , ketika seorang mahasiswa kedokteran Paul Langerhans menemukan populasi sel dendritik intraepidermal pada kulit manusia yang diwarnai dengan gold chloride. ${ }^{7}$ Karena sel ini mempunyai morfologi dendritik (tonjolan-tonjolan panjang pada permukaan selnya), maka Langerhans mengasumsikan bahwa sel ini mungkin merupakan tipe baru dari sel saraf. Setelah lebih dari 100 tahun kemudian, disarankan bahwa sel Langerhans mungkin merupakan leukosit. Pada awal 1970-an sel-sel dendritik diidentifikasi dan dikarakterisasi sebagai sel penyaji antigen khusus derivat sumsum tulang dan kemudian pemahaman mengenai fungsi-fungsinya mulai berkembang. ${ }^{8}$

\section{Definisi}

Sel Langerhans ialah sel dendritik penyaji antigen berasal dari sumsum tulang yang umumnya bertempat pada stratum spinosum (Gambar 2). ${ }^{9,10}$ Oleh karena selsel Langerhans berada dalam epidermis, maka diperkirakan sel-sel ini menyediakan perangkap untuk antigen eksternal yang ditemukan pada kulit. ${ }^{11}$

\section{Asal sel Langerhans}

Sel Langerhans berasal dari prekursor sel CD34+ (CD/cluster of differentiation) dalam sumsum tulang. Dengan pemberian granulocyte macrophage colony stimulating factor (GM-CSF) dan juga interleukin-4 (IL-4) atau tumor necrosis factor- $\alpha$ (TNF- $\alpha$ ), sel Langerhans dapat dikultur dari prekursor sel CD34+ (Gambar 3). Berbeda dengan sel dendritik 
lainnya, sel Langerhans memerlukan TGF$\beta$ dalam perkembangannya. Selain itu sel Langerhans secara unik mengekspresikan CD1a, granula Birbeck, langerin, dan molekul adesif E-chaderin., ${ }^{2,13}$

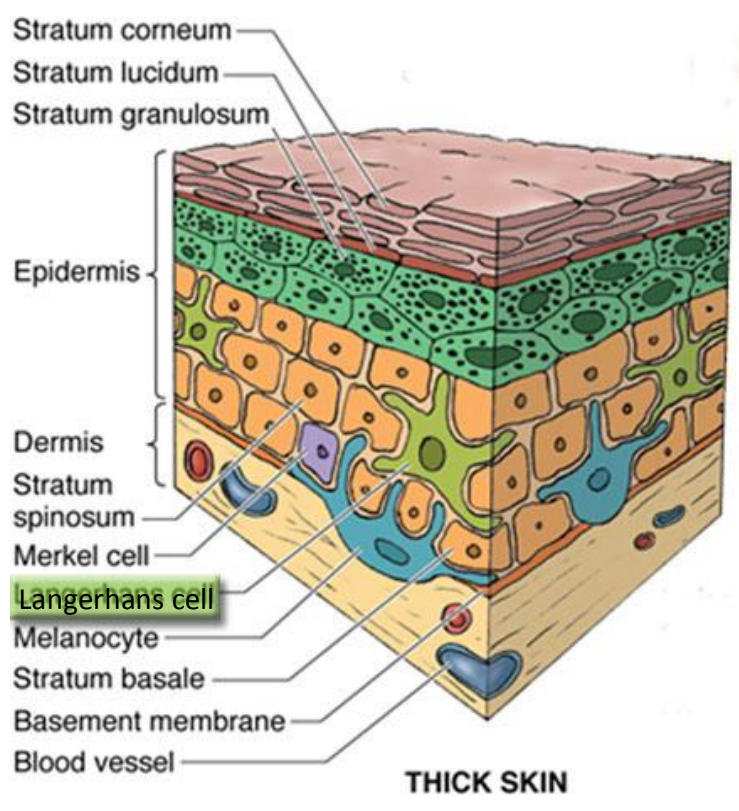

Gambar 2. Sel Langerhans di epidermis kulit tebal. Sumber: Gartner et al, $2011 .^{12}$

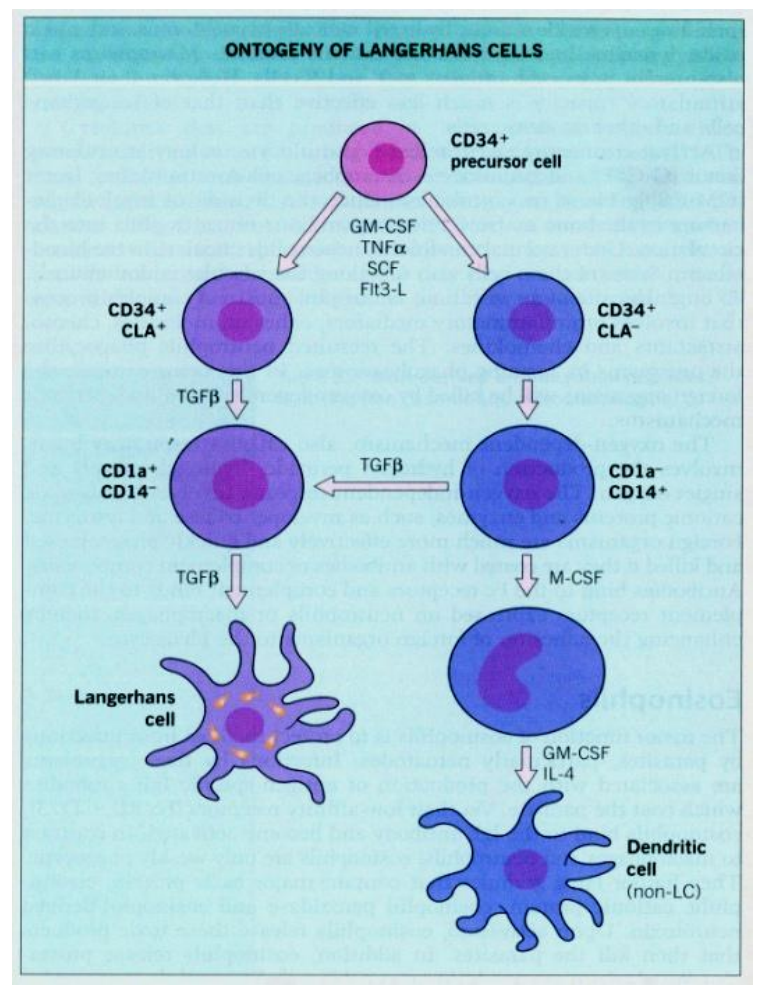

Gambar 3. Asal mula sel Langerhans. Sumber: Bolognia et al, $2008^{2}$

\section{Morfologi}

Sel Langerhans tidak dapat diidentifikasi dengan fikasasi rutin dan pewarnaan histologi biasa, tetapi harus menggunakan mikroskop elektron atau tehnik histokimia (Gambar 4).

Gambaran struktur halus sel Langerhans memperlihatkan adanya organel berbentuk batang dengan panjang $\pm 0,8-2 \mu \mathrm{m}$, disebut granula Birbeck. ${ }^{14}$ Fungsi granula Birbeck masih diperdebatkan. Akhir-akhir ini telah diidentifi-kasi $\mathrm{Ca}^{2+}$ dependent lectin dengan spesifisitas pengikatan manosa (disebut langerin), yang berhubungan dengan granula Birbeck, dan bahkan dapat menginduksi pembentukan granula tersebut. Secara histokimia, sel Langerhans manusia dapat divisualisasikan dengan pewarnaan adenosin trifosfatase (ATPase), pewarnaan tahan formalin, enzim sulfhydryldependent. Penanda yang selalu terdapat pada sel Langerhans ialah CD45 panhematopoetik, major histocompatibility complex class II (MHC kelas II), CD1a, protein S100, vimentin dan granula Birbeck yang berkaitan dengan langerin. ${ }^{2}$

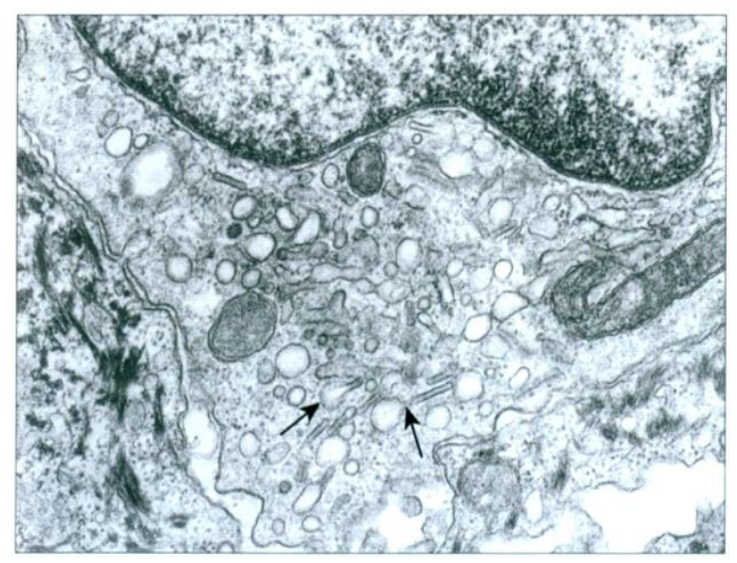

Gambar 4: Sel Langerhans dengan mikroskop elektron Sumber: Bolognia et al, 2008. ${ }^{2}$

\section{Fungsi}

Sel Langerhans berfungsi sebagai sel penyaji antigen yang berada di epidermis oleh karena mempunyai morfologi dendritik dengan fenotip permukaan sel sebagai penyaji antigen dan kemampuan 
bermigrasi ke area yang banyak sel $\mathrm{T}$. Tonjolan sel yang panjang seperti dendrit memfasilitasi sel Langerhans untuk mengambil antigen protein atau kompleks hapten-protein sepanjang epidermis. ${ }^{6}$

\section{Reseptor permukaan}

\section{Produk $M H C$}

Respon imun terhadap antigen asing ditentukan oleh ekspresi molekul MHC spesifik yang dapat mengikat dan menyajikan fragmen peptida protein/antigen tersebut pada sel T. Oleh karena molekul MHC terdapat pada membran dan tidak disekresi, maka limfosit $\mathrm{T}$ hanya dapat mengenali antigen asing bila terikat pada permukaan sel lain. ${ }^{1}$ Sebagai sel penyaji antigen, sel Langerhans memperlihatkan ekspresi kuat dari seluruh gen MHC kelas II. ${ }^{15}$

\section{Reseptor Fc (FcR)}

Reseptor Fc ialah molekul yang diekspresikan pada permukaan berbagai sel, yang dapat mengenali dan mengikat daerah Fc dari kelas dan subkelas imunoglobulin. Pada sel Langerhans ditemukan ekspresi reseptor $\operatorname{IgE}$ (FceR) berafinitas tinggi. ${ }^{16}$

\section{Integrin dan adhesin}

Integrin merupakan protein permukaan yang fungsi utamanya memerantarai adhesi, baik antara sel dan sel maupun sel dan matriks ekstrasel. Integrin bersama adhesin berkontribusi pada pengikatan sel dan homing, dimana kedua hal ini sangat penting dalam kerja sel Langerhans. Beberapa contoh integrin pada sel Langerhans yaitu intercellular adhesion molecule-1 (ICAM-1, CD54), ICAM 3 (CD50), lymphocyte function-associated antigen-3 (LFA-3, CD58), dan $\beta_{2}$ integrin (CD18). ${ }^{6}$

\section{BAHASAN}

Sel Langerhans mengambil antigen dengan cara memfagositosis serta memanfaatkan reseptor membran untuk memicu pengambilan antigen. Reseptor untuk pengambilan antigen termasuk reseptor yang berafinitas tinggi terhadap IgE yaitu FceR dan FceRI, reseptor komplemen CD11b dan CD11c, lectin C (reseptor pengikat mannan), dan DEC205 (CD-205). ${ }^{6,13}$

Setelah terjadi pengambilan antigen, proses selanjutnya pemrosesan antigen oleh MHC kelas II. Target utama MHC kelas II yaitu antigen eksogen yang diambil melalui makro atau mikropinositosis, atau melalui reseptor yang dimediasi endositosis. Degradasi protein akhirnya terjadi di dalam lisosom, yang menghasilkan peptida dengan panjang 15-22 residu asam amino. Fragmen peptida memasuki kompartemen endosomal khusus mengandung molekul MHC kelas II, yang dihasilkan di dalam retikulum endoplasma (Gambar 5). ${ }^{2}$

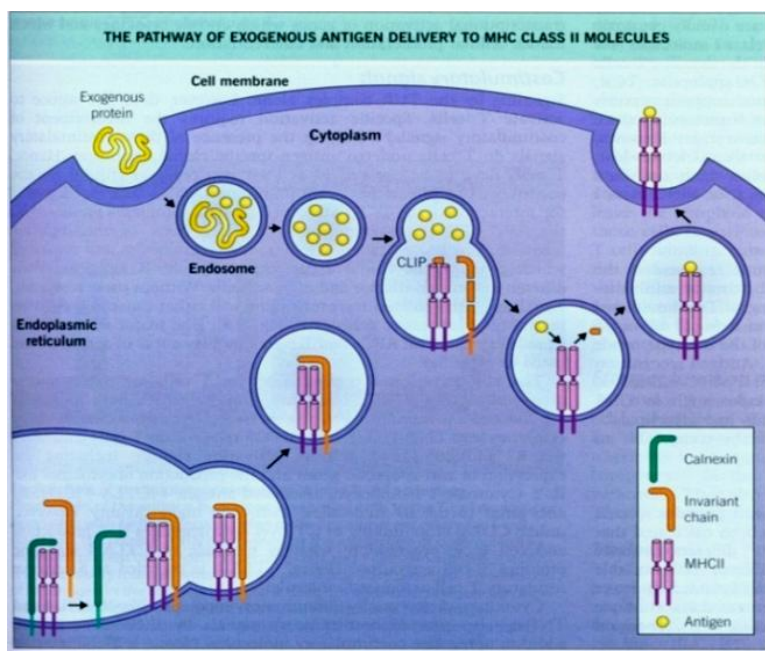

Gambar 5: Jalur penghantaran antigen eksogen pada molekul MHC kelas II. Sumber: Bolognia et al, $2008 .^{2}$

MHC kelas II yang baru disintesis berasosiasi dengan sebuah rantai invarian yang menghambat disosiasi molekul MHC kelas II belum terikat antigen dan mengangkut molekul MHC kelas II dari retikulum endoplasma ke kompartemen endosomal khusus sehingga molekul MHC dapat berinteraksi dengan fragmen peptida antigen. Rantai invarian dibelah oleh protease, dan meninggalkan sebuah fragmen kecil disebut CLIP (kelas II-terkait peptida invarian) yang terikat pada molekul MHC. 
Pada interaksi dengan peptida antigen, fragmen CLIP dilepaskan dari kompleks dan digantikan oleh peptida antigen. Akhirnya MHC kelas II yang terikat antigen peptida diekspresikan pada permukaan sel, memungkinkan pengenalan antigen oleh sel $\mathrm{T}$ yang membawa TCR yang sesuai. ${ }^{2}$

Selain pemrosesan antigen dilakukan oleh MHC kelas II, sel Langerhans memiliki reseptor CD1 yang tidak dimiliki oleh jenis sel dendritik lainnya. Molekul CD1 menyajikan antigen dalam bentuk lipid dan glikolipid baik eksogen maupun endogen. ${ }^{17,18}$ Molekul CD1 dihasilkan di dalam retikulum endoplasma dan diekspresikan pada membran plasma, menuju ke permukaan melalui penghantaran oleh vesikel. $^{13}$

Kostimulasi diperlukan untuk menginisiasi respon imun produktif oleh sel $\mathrm{T}$. Kostimulator yang paling penting pada sel $\mathrm{T}$ naif ialah $\mathrm{CD} 28$; dan ligannya yang sesuai yaitu CD80 (B7-1) dan CD86 (B7-2), terdapat pada sel penyaji antigen matur. CD80 dan CD86 merupakan anggota pertama dari subfamili B7 yang lebih besar. ${ }^{13}$

Kolgen et al $(2002)^{19}$ menyatakan bahwa jumlah sel Langerhans berkurang pada saat kulit terpapar oleh sinar ultraviolet (UV). Penelitian ini ditujukan untuk mengetahui mekanisme ketidakhadiran sel Langerhans oleh induksi UV. Mekanisme yang paling banyak diterima yaitu akibat apoptosis dan migrasi. Penilaian apoptosis secara in vivo dilakukan dengan menyinari kulit bokong minimal enam dosis eritema UV-B. Ternyata hanya ditemukan sedikit sel Langerhans yang mengalami apoptosis pada potongan kulit yang terpajan oleh UV-B. Metode yang digunakan untuk mendeteksi migrasi sel Langerhans yaitu dengan menangkap sel-sel ini dari cairan lepuhan. Lepuhan dikembangkan pada sisi fleksor lengan bawah dari sukarelawan sehat pada beberapa titik waktu setelah terpajannya kulit dengan minimal enam dosis eritema UV-B. Cairan lepuhan dikumpulkan dan sel Langerhans terdeteksi dalam cairan lepuhan pada kulit yang terpajan UV-B, dan tidak pada kulit yang tidak terpajan. Sel Langerhans yang terdapat pada cairan lepuhan positif terwarnai untuk kerusakan DNA (cyclobutyl pyrimidine dimer), memperlihatkan sel tersebut berasal dari epidermis yang terkena UV-B. Ketidakhadiran sel Langerhans yang terinduksi UV-B sepertinya terutama disebabkan oleh migrasi.

Sel Langerhans merupakan sel yang memicu awal terjadinya dermatitis kontak alergi yaitu pada fase sensitisasi. ${ }^{20}$ Hapten yang masuk ke dalam epidermis melewati stratum korneum akan ditangkap oleh sel Langerhans dengan cara pinositosis, kemudian diproses secara kimiawi oleh enzim lisosom atau sitosol serta dikonjugasikan pada molekul MHC menjadi antigen lengkap. Pada awalnya sel Langerhans dalam keadaan istirahat, tetapi keratinosit yang terpajan oleh hapten (yang juga mempunyai sifat iritan) akan melepaskan sitokin (IL-1) yang selanjutnya mengaktifkan sel Langerhans sehingga mampu menstimulasi sel T. Aktivasi tersebut akan mengubah fenotip sel Langerhans dan meningkatkan sekresi sitokin tertentu (misalnya IL-1) serta ekspresi molekul permukaan sel termasuk MHC kelas II, ICAM-1, LFA-3 dan B7. Sitokin proinflamasi lain yang dilepaskan oleh keratinosit yaitu TNF- $\alpha$, yang dapat mengaktivasi sel $\mathrm{T}$, makrofag dan granulosit, menginduksi perubahan molekul adhesi sel dan pelepasan sitokin juga meningkatkan MHC kelas II. $^{21}$

TNF- $\alpha$ menekan produksi E-cadherin yang mengikat sel Langerhans pada epidermis; juga menginduksi aktifitas gelatinolisis sehingga memperlancar sel Langerhans melewati membran basalis bermigrasi ke kelenjar getah bening setempat melalui saluran limfe. Di dalam kelenjar getah bening, sel Langerhans memresentasikan kompleks MHC-antigen kepada sel Th spesifik (yang mengekspresikan molekul CD4 yang mengenali MHC sel Langerhans) dan kompleks reseptor sel TCD3 (yang mengenali antigen yang telah diproses). ${ }^{21}$

Sel Langerhans menyekresi IL-1 yang menstimulasi sel T untuk menyekresi IL-2 dan mengekspresikan reseptor IL-2 (IL- 
2R). Sitokin ini akan menstimulasi proliferasi sel Th spesifik, sehingga jumlahnya bertambah banyak. Turunan sel ini yaitu sel $\mathrm{T}$ memori (sel $\mathrm{T}$ teraktivasi) akan meninggalkan kelenjar getah bening dan beredar ke seluruh tubuh. Pada saat tersebut individu menjadi tersensitisasi. Fase ini rata-rata berlangsung selama 2-3 minggu. ${ }^{21}$

Kortikosteroid merupakan salah satu jenis obat imunosupresan yang digunakan untuk menekan respon imun seperti pada dermatitis kontak alergi. Kortikosteroid dapat menurunkan jumlah limfosit secara cepat terutama bila diberikan dalam dosis besar. Studi terbaru menunjukkan bahwa kortikosteroid menghambat proliferasi sel limfosit $\mathrm{T}$, imunitas seluler termasuk didalamnya yaitu sel Langerhans, dan ekspresi gen yang menyandi berbagai sitokin yaitu IL-1, IL-2, IL-6, IFN- $\alpha$ dan TNF- $\alpha$ (Gambar 6). Pada pasien dengan dermatitis kontak alergi dapat diberikan kortikosteroid untuk mengatasi proses inflamasi. ${ }^{22}$

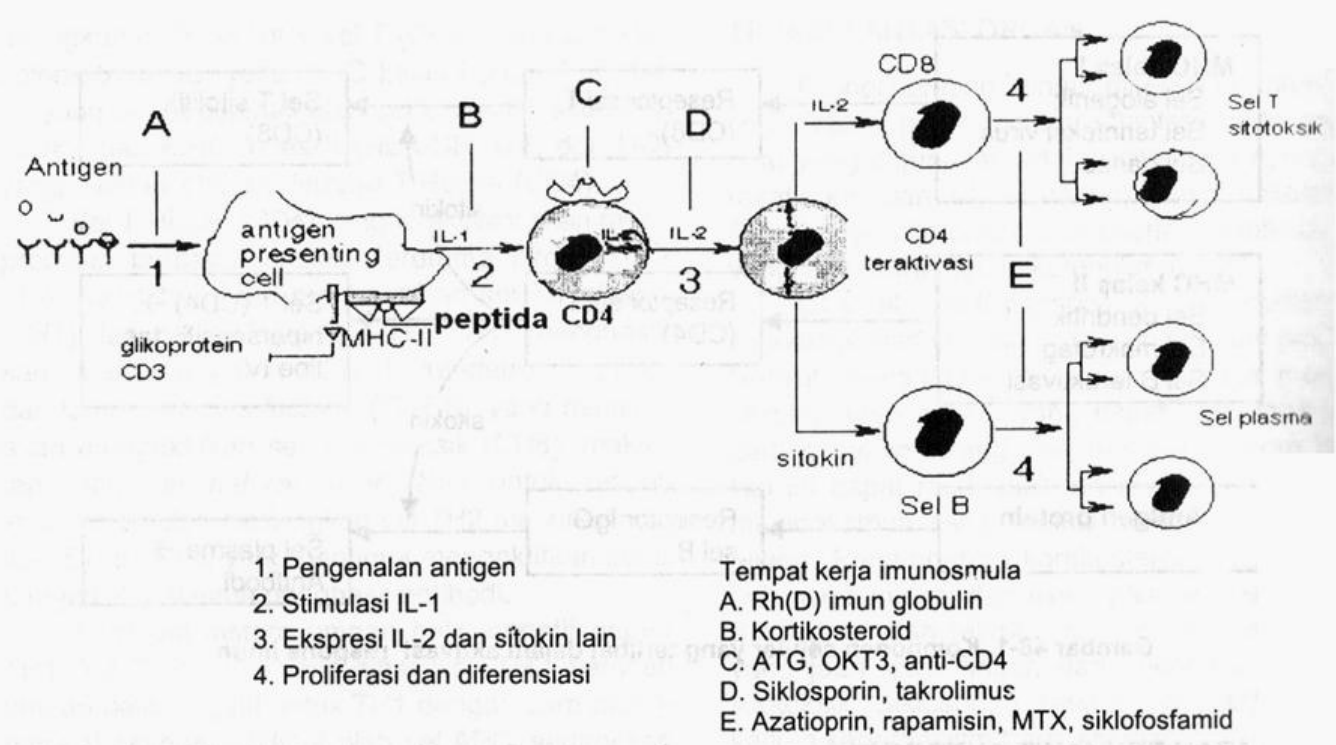

Gambar 6: Tempat kerja berbagai imunosupresan. Sumber: Nafrialdi, 2007. ${ }^{22}$

\section{SIMPULAN}

Sel Langerhans ialah jenis sel dendritik kulit yang berfungsi menyajikan antigen dengan diproses terlebih dahulu oleh MHC kelas II agar dapat dikenal oleh sel $\mathrm{T}$ sehingga dapat diberikan respon imun yang sesuai. Pada dermatitis kontak alergi, sel Langerhans mencetuskan terjadinya fase sensitisasi.

\section{DAFTAR PUSTAKA}

1. Kresno SB. Imunologi: Diagnosis dan Prosedur Laboratorium (Edisi 4). Jakarta: Balai Penerbit FKUI. 2007.

2. Bolognia JL, Jorizzo JL, Rapini RP. Dermatology (Second Edition). St
Louis: Mosby Elsevier. 2008.

3. Abbas AK, Lichtman AH. Basic Immunology: Functions and Disorders of the Immune System (Third Edition). Philadelphia: Saunders Elsevier. 2009. p. 45-65.

4. Antigen presenting cells. [homepage on the internet] 2011. Nodate [cited 2011 Jun 25] Available from: http://www. wellness.com/reference/allergies/antigen -presenting-cells/.

5. Three types of antigen presenting cell. [homepage on the internet] 2011. Nodate [cited 2011 Jun 25]. Available from: http://sprojects.mmi.mcgill.ca/ immunology/APC_text.htm.

6. Blauvelt A. Langerhans cells. In: Delves PJ, Roitt IM, editors. Encyclopedia of 
Immunnology (Second Edition). London: AP, 1998; p. 1528-32 [ebook].

7. Numahara T, Tanemura M, Numahara K, Moriue J, Shirahige Y, Yokoi I et al. Spatial statistic for epidermal Langerhans cells. Forma. 2009;24:4559.

8. Lucas A, MacPherson G. Langerhans cell: immigrants or residents. Nat. Immunol. 2002;3:1125-26.

9. Romani N, Clausen BE, Stoitzner P. Langerhans cells and more: langerinexpressing dendritic cell subsets in the skin. Immunol Rev. 2010;234:120-141.

10. Gartner LP, Hiatt JL. Atlas Berwarna Histologi (Edisi 5). Jakarta: Binarupa Aksara. 2011.

11. Cumberbatch M, Dearman RJ, Griffiths CE, Kimber I. Epidermal Langerhans cell migration and sensitisation to chemical allergens. Apmis. 2003; 111:797-804.

12. Gartner LP, Hiatt JL, Strum JM. Biologi Sel dan Histologi (Edisi 6). Jakarta: Binarupa Aksara. 2011.

13. Lipscomb MF, Masten BJ. Dendritic cells: immune regulators in health and disease. Physiol Rev. 2002;82:97-130.

14. Weinberg JB. Mononuclear phagocytes. In: Greer JP, Foerster J, Lukens JN, Rodgers GM, Paraskevas F, Glader B, editors. Wintrobe's Clinical Hematology (Eleventh Edition). Philadelphia: Lippincott Williams and Wilkins, 2004; p. 544-8.

15. Steinman RM. The dendritic cell system and its role in immunogenicity. Annu Rev Immunol. 1991;9:271-296.
16. Wang B, Rieger A, Kilgus O, Ochiai K, Maurer D, Fodinger $D$ et al. Epidermal Langerhans cells from normal human skin bind monomeric IgE via $\mathrm{Fc}$ epsilon RI. J Exp Med. 1992;175:1353-65.

17. Shortman K, Caux C. Dendritic cell development: multiple pathways to nature's adjuvants. Stem Cells. 1997;15:409-419.

18. McCance KL, Huether SE, Bashers VL, Rote NS. Pathophysiology: The Biologic Basic for Disease in Adults and Children (Sixth Edition). St Louis: Mosby Elsevier. 2010. p. 247-252.

19. Kolgen W, Both $H$, Weelden HV, Guikers KL, Koomen CA, Knol EF et al. Epidermal Langerhans cell depletion after artificial ultraviolet B irradiation of human skin in vivo: apoptosis versus migration. J Invest Dermatol. 2002;118:812-817.

20. Sinakin-Silberberg I, Thorbecke GJ. Contact hypersensitivity and Langerhans cell. The Journal of Investigative Dermatology. 1990;75:61-67.

21. Hamzah M. Erupsi obat alergik. In: Djuanda A, Hamzah M, Aisah S, editors. Ilmu Penyakit Kulit dan Kelamin (Edisi Kelima). Jakarta: FKUI, 2007; p. 138-46.

22. Nafrialdi. Imunomodulator, imunosupresan dan imunostimulan. In: Gunawan SG, Setiabudy R, Nafrialdi, Elysabeth, editors. Farmakologi dan Terapi (Edisi 5). Jakarta: Balai Penerbit FKUI, 2007; p. $760-1$. 